\title{
Ageing Labour Forces: Promises and Prospects
}

\author{
by Philip Taylor (ed.) \\ Northampton, MA: Edward Elgar, 2008 \\ ISBN 978-1-84542-425-1 \\ US $\$ 125.00,236 \mathrm{pp}$.
}

\author{
Reviewed by Herbert C. Northcott \\ Department of Sociology \\ University of Alberta \\ herb.northcott@ualberta.ca
}

The age of entry into the labour force and the age of exit from the labour force are socially and historically contingent. Over the twentieth century many countries expanded their educational systems, such that an increasing proportion of young people were spending an increasing number of years in school and/or in training. As young people spend more and more years being educated, their entry into the labour force as full-fledged and full-time workers is delayed. As for the older workers, over the twentieth century the trend in many countries was toward facilitating an earlier and earlier exit of older workers from the labour force, through the implementation of retirement policies and programs. Indeed, the battle cry in Canada only a few years ago, it seems, was "Freedom 55." The Freedom 55 discourse promised workers that if they invested wisely they could be free from the need to work in the paid labour force by the age of 55 and spend the next three decades of their statistically remaining life in comfortable pensioned leisure. Accordingly, labour force participation rates showed a trend in the late twentieth century towards earlier retirement.

What a difference a decade or two make! Taylor's collection of essays illustrates a dramatic turnaround in the early twenty-first century in the perceived desirability of earlier versus later retirement. This collection of essays examines the ageing labour forces in Australia, Japan, Canada, United Kingdom, United States of America, Netherlands, France, and Germany. In every one of these countries, the population and the labour force are ageing as these countries complete their demographic transitions, moving to low fertility and low mortality and an increasing average age. An ageing population, coupled with late entry into the labour force and early exit from the labour force, decreases the relative size of the labour force and increases the labour force dependency ratio (the ratio of persons not in the labour force to persons in the labour force). As the labour force dependency ratio increases, the increasing number of persons in society who are not in the labour force and are supported by a shrinking labour force becomes increasingly problematic, especially in terms of paying for the healthcare and income security of the increasing proportion of retirees in the population. In addition, the shrinking labour 
force foreshadows labour shortages. As the baby boom enters old age over the period of time from 2011 to 2031, this situation will be exacerbated unless trends towards early retirement are reversed. As a solution, a discourse of positive ageing (and also successful, productive, healthy aging) has emerged that argues for and justifies the continuation of older workers in the labour force rather than their early exit from employment to retirement.

While the trend in the late twentieth century was towards early retirement (in workers' early sixties, and even fifties), the preference of policymakers in the early twenty-first century is the implementation of policies and programs that encourage ageing workers to stay in the labour force longer. These newly designed policies and programs, it is argued, will have to counter incentives to early retirement, emphasize disincentives to retire early, remove barriers to delayed retirement, and increase incentives to remain in the labour force longer. Each country reviewed in this collection of essays is attempting to find ways to counter the trend to early retirement and foster the retention of ageing workers in the labour force.

Strategies discussed include the following: combating ageism and age discrimination, changing perceptions about the value of older workers, encouraging active productive healthy ageing, doing away with mandatory retirement, guaranteeing the right to work for older persons who are able to work and wish to work, providing incentives for workers to retire later, changing existing incentives which encourage workers to retire early or encourage employers to support early retirement, increasing pensionable ages and age of eligibility for old-age income security programs, providing incentives for employers to hire and retain older workers, developing life-long learning opportunities, improving the quality of work for workers of all ages, providing for flexible or part-time work and career breaks with temporary exits from the labour force (for re-training or caregiving, for example), preventing unemployment and involuntary early retirement of older workers, facilitating the re-employment of older workers who lose their jobs, and providing for gradual or partial or phased retirement, that is, blurring the boundary between work and retirement. In retaining ageing workers in the labour force, it is important to focus on retaining them in meaningful and adequately remunerative employment. Retaining ageing workers in the labour force should not mean marginalizing these older workers in lowpaid, low-status jobs in the labour force periphery. The motivation to increase the labour participation rates of older workers should display concern not only about the effects on the economy and on society but also a concern for the older workers themselves.

While much of this book leads the reader to accept the inevitability of working longer and retiring later, the concluding chapter raises questions about this inevitability. What policymakers deem best for society as a whole with regards to the retention of older workers in the labour force depends on employers believing that retaining older workers is good for business, and it is not clear that employers will readily accept this point of view and buy in to policies and programs designed to retain the older worker. Age discrimination in employment remains. Business has the option of seeking labour elsewhere in the global economy. The older worker who becomes unemployed has a much greater difficulty finding suitable re-employment. Nevertheless, this book argues convincingly that there are considerable forces at work in mature industrial economies that are reversing the previous trend to early retirement and effecting a trend towards later retirement instead. The turnaround has been, and will be, dramatic indeed. 